\title{
ASPLENIUM PLENUM: A FERN WHICH SUGGESTS AN UNUSUAL METHOD OF SPECIES FORMATION ${ }^{1}$
}

\author{
Virginia M. MorzentT \\ Department of Botany and Botanical Gardens, University of Michigan, Ann Arbor
}

A $\quad$ B S T R A C T

\begin{abstract}
Morphological data, chromosome behavior, and occurrence strongly suggest that the Florida fern known as Asplenium plenum arose as a cross $\left(\mathrm{AAB}_{1} \mathrm{~B}_{2}\right)$ between a sexual $2 x$ species, $A$. abscissum (AA), and a "sterile" $3 x$ hybrid, $A$. curtissii $\left(\mathrm{AB}_{1} \mathrm{~B}_{2}\right)$. A mechanism is described whereby such an origin is possible: $A$. curtissii, among other so-called "sterile" hybrids, has the ability to produce unreduced spore mother cells capable of becoming spores directly. Such spores are able to form gametophytes with viable sperms and have the potential of producing sporophytes apogamously. It is highly probable that this heretofore overlooked process has operated in the origin of the hybrid fern, A. plenum, and is the first to be reported in the literature.
\end{abstract}

The exceedingly Rare Florida fern known as Asplenium plenum E. P. St. John was first discovered in 1936 in a limestone cavern near Lecanto, Fla. In 1938 St. John (Small, 1938) described this plant as a normal species, known then from that single locality. Small (1938) says that $A$. plenum "was at first considered a form of Asplenium curtissii, from which it differs in similar ways and to about the same extent as that fern differs from $A$. verecundum." In view of the studies to be described below the latter statement has proved to be significant. In the mid1950's specimens of $A$. plenum were discovered at a new locality (Indian Field Ledges in Sumter Co., Fla.) by E. S. Ford and Thomas Darling, Jr. In describing his observations at this locality, Darling (1961) wrote: "At the time of my 1957 visit I ... supposed the entire lot to be $A$. curtissii. Not until I revisited Indian Field Ledges in 1958 and collected more specimens of these ferns did I suspect that two different species of Asplenium ( $A$. curtissii and $A$. plenum) were represented." More recently Wagner $(1963 \mathrm{a}, \mathrm{b})$ suggested that $A$. plenum is of hybrid origin and that its most probable parents are $A$. abscissum and $A$. cristatum. The purpose of the current paper is to present evidence in support of a new hypothesis for the origin of Asplenium plenum, which may involve an undescribed process in the formation of certain fern species.

The TAXa Involved-The five taxa included in the complex under discussion are shown in

\footnotetext{
${ }^{1}$ Received for publication 5 November 1966.

This study was supported in part by National Science Foundation Grants G-10846 and GB-3366. The author thanks Professor Warren H. Wagner, Jr., for helpful suggestions; Dr. E. S. Ford, Mr. Thomas Darling, Jr., and Mr. C. E. Delchamps for sending living plants upon which this research is based; and the staff of the University of Michigan Botanical Gardens for cultivating the plants.
}

Fig. 1: A. cristatum Lam., A. abscissum Willd., A. plenum E. P. St. John, A. curtissii Underw., and $A$. verecundum Chapm. The habitats of all are similar. As summarized by Wherry (1964), they grow on shady, wooded limestone ledges and walls of sinks. All five have been reported from at least one locality, Indian Field Ledges. Darling (1962) reported that "Asplenium abscissum and $A$. verecundum were common every. where, and A. plenum was luxuriant on a long, low-lying boulder, with $A$. curtissii less plentiful on rocks to the southwest." Asplenium cristatum, however, was not recorded from this locality until Wagner (1963a) found a single plant.

Recent studies on cultivated plants have resulted in the following data: Three are normal species, two being diploids and one a tetraploid; the other two are hybrids, a triploid and a tetraploid (Fig. 2-6). Both A. cristatum and $A$. abscissum are $2 x$ with $n=36$ and have 64 normal, monolete, meiotic spores per sporangium; A. verecundum is $4 x$ with $n=72$ and it also has 64 meiospores per sporangium. Asplenium curtissii is a $3 x$ hybrid with 108 chromosomes, forming mostly univalents at meiosis with an irregular number of bivalents, varying from 1 to 17 pairs in the observations made. In sporogenesis $A$. plenum also behaves as a hybrid but is a tetraploid, $2 n=144$, and exhibits many more pairs, usually some 60 -odd bivalents. Up to the present, where the spores produced by these two hybrids have been described, they have been called "abortive."

Asplenium curtissii is obviously a simple hybrid between two normal species. It is analogous to dozens of such taxa now known in the literature of pteridology. This taxon was described by Underwood from the vicinity of Ocala, Fla., in 1906, although he did not regard it as a cross. As discussed by Wagner (1963a), the plant is,

[The Journal for September (54:931-1059) was issued 17 October 1967]

American Journal of Botany, Vol. 54: No. 9, 1967 


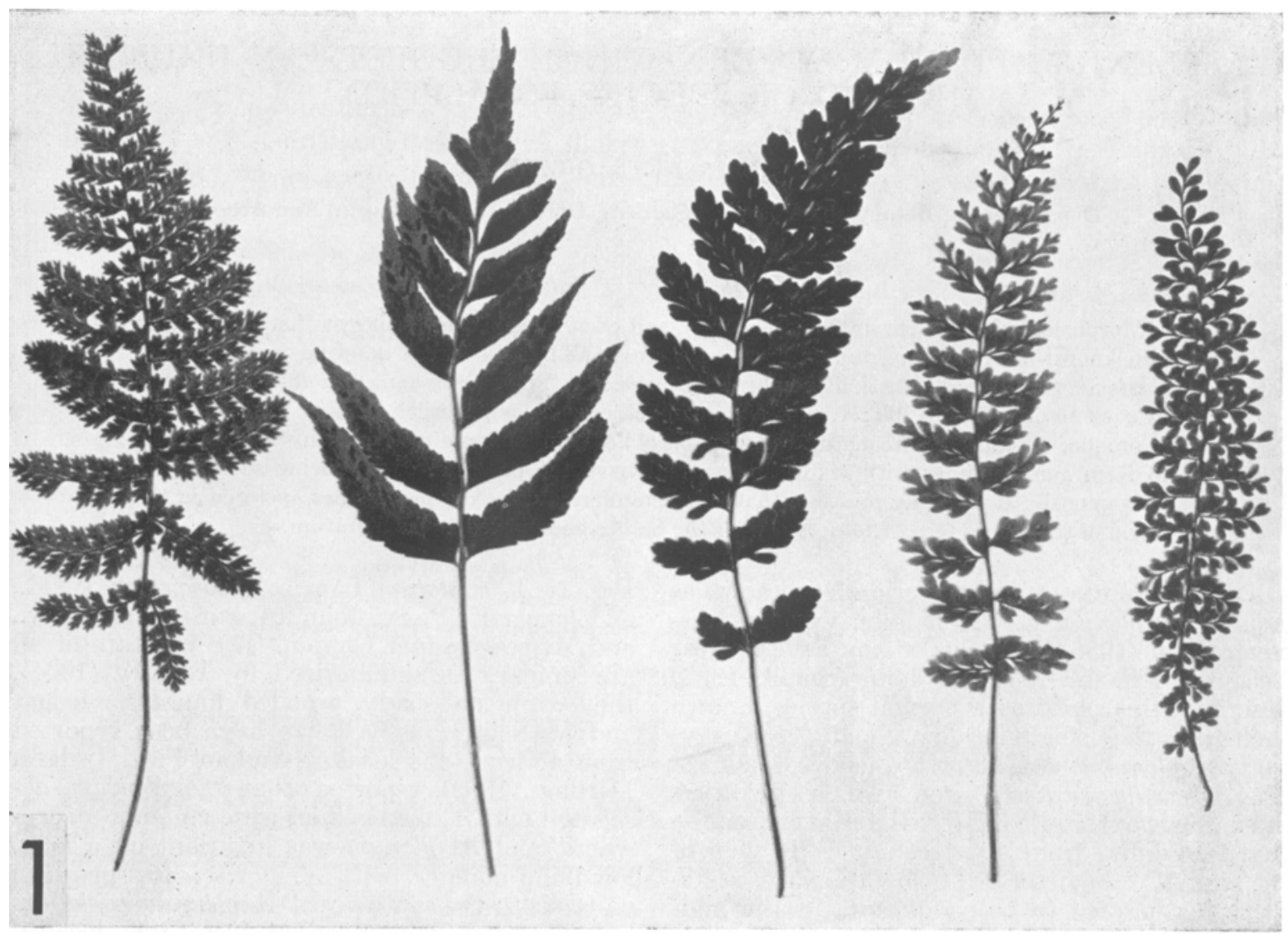

Fig. 1. (left to right) A. cristatum (Jamaica); A. abscissum (Marion Co., Fla.); A. plenum (Sumter Co., Fla.); A. curtissiz (Sumter Co., Fla.); A. verecundum (Sumter Co., Fla.).

however, a morphological intermediate between $A$. verecundum and $A$. abscissum, though in overall appearance it tends to look somewhat more like the former parent. Since $A$. verecundum contributes a genome of 72 chromosomes while A. abscissum contributes a genome of 36 chromosomes, it is not surprising that their cross inclines toward the former. As shown in Table 1, however, a more detailed study of the morphology of these plants has demonstrated that in some characters $A$. curtissii is almost exactly intermediate between its parents. In the degree of cutting of the pinnae it tends to resemble $A$. verecundum more. But in the average length of the longest pinnae, the hybrid is more nearly intermediate, as shown by the proximity of the actual and predicted averages (predicted average based on parental measurements) given in Table 1. Another character of the hybrid showing intermediacy is the pinna angle from the rachis (using dried specimens). As shown in the table the predicted pinna angle average for $A$. curtissii is $59^{\circ}$ while the actual average measured $60^{\circ}$.

The pairing behavior of $A$. plenum is rather peculiar in view of the seemingly abortive spores. There are 144 chromosomes with a high degree of bivalent formation at meiosis but usually with some 10 to 20 unpaired chromosomes. In his discussion of the nature of this plant, Wagner (1963a) stated that such a cytological condition must mean that either two $2 x$ or two $4 x$ species participated in the formation of $A$. plenum if it is, in fact, a hybrid. At the time of his writing the most logical parental candidates seemed to be $A$. abscissum, $n=36$, and $A$. cristatum, also with $n=36$. At first sight $A$. plenum appears to be somewhat intermediate between these two sexual species. However, if it is really the allotetraploid cross of these two taxa (excluding morphology for the present), there are several major difficulties: (1) There is usually incomplete pairing at meiosis. Even though there are numerous pairs, the number of univalents is more than one would expect. A normal allotetraploid ferm usually has complete pairing. (2) Normal monolete meiotic spores are not formed in $A$. plenum. Its spores have been described as "abortive" and unable to germinate, which is unlike typical fern allotetraploids. (3) The only time $A$. cristatum has ever been reported as growing together with $A$. abscissum in Florida was by Wagner (1963a) and there was but a single plant of 


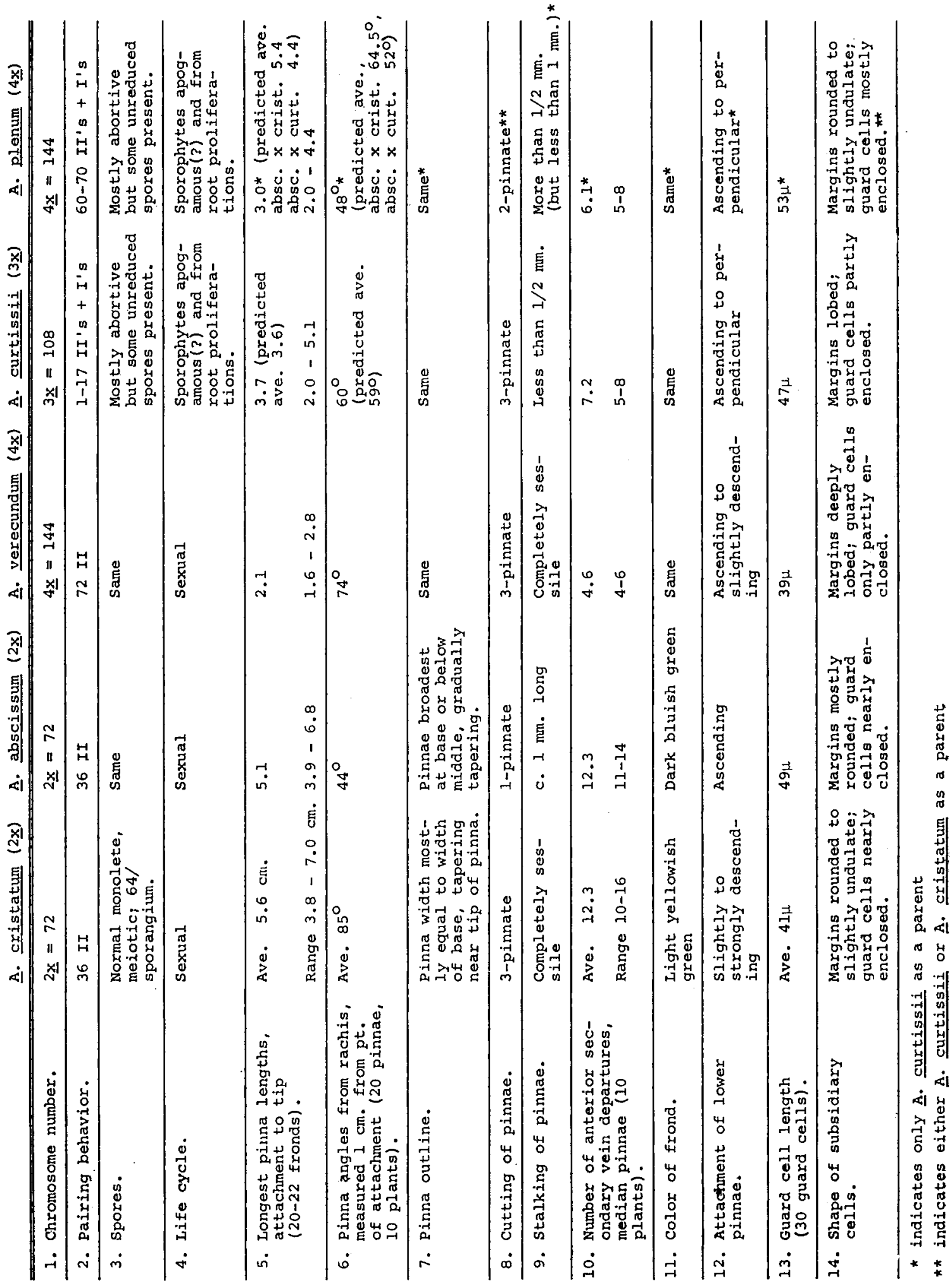




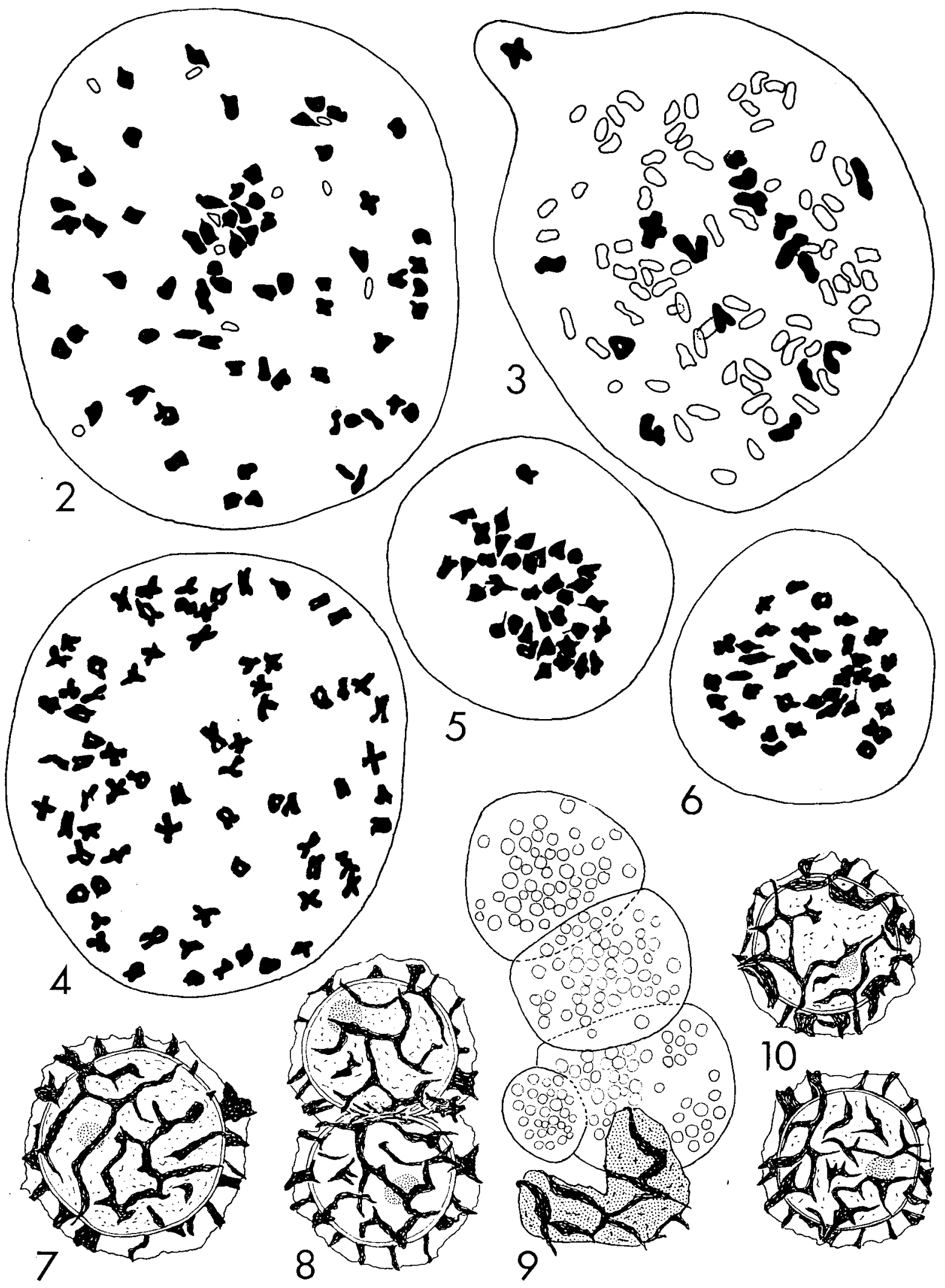


the former at a distance of about one-quarter mile from $A$. plenum (Wagner, personal communication). These facts tend to make the $A$. abscissum $\times$ cristatum origin for $A$. plenum unlikely; the data to be described below indicate a different origin. I wish to make the following proposal-namely, that $A$. plenum is not the allotetraploid hybrid between $A$. abscissum and $A$. cristatum, but rather that it is the cross between a $2 x$ sexual species, $A$. abscissum, and the "sterile" $3 x$ hybrid, A. curtissii.

Monphological Evidence-A careful morphological comparison of $A$. plenum with its presumed relatives abundantly supports the rather remarkable conclusion stated above. Table 1 summarizes this evidence. Three characters which tend to preclude any involvement of $A$. cristatum at all are as follows: (1) pinna lengths; (2) the angles of the pinnae with the rachis; and (3) the outlines of the pinnae. As shown in the table, the greater proximity between actual and predicted averages for measurements with $A$. curtissii as a parent strongly suggests its participation in the formation of $A$. plenum. This same tendency for $A$. plenum to indicate an $A$. $a b$ scissum $\times$ curtissii origin rather than an $A$. abscissum $\times$ cristatum origin can also be seen in the number of anterior secondary veins in the pinnae, the pinna angles from the rachis, the pinna outlines, the cutting and stalking of the pinnae, the attachment of the lower pinnae, the leaf color, the guard cell length, and the subsidiary cell shape (Table 1; Fig. 1, 11-20).

Cr'Togene'TC Evidence-The hypothesis involving $A$. curtissii as one of the parents of $A$. plenum finds further support in the cytogenetic behavior of the latter. It is an allotetraploid but may not be formed in the usual way, i.e., by the formation of a $2 x$ hybrid with genomes "AB" and subsequent doubling to give genomes "AABB" which would make possible perfect pairing, normal meiosis, and regular monolete spores. Asplenium plenum, with one genome from $A$. abscissum, " $A$," and the genetic complement of $A$. curtissii, " $\mathrm{AB}_{1} \mathrm{~B}_{2}$ " ("A" from $A$. abscissum, " $\mathrm{B}_{1} \mathrm{~B}_{2}$ " from $A$. verecundum), has the condition " $A A B_{1} B_{2}$." The " $A$ " genomes can pair perfectly, forming 36 of the bivalents seen at meiosis. Although no $2 x$ progenitor has been found, it is possible that $A$. verecundum is itself an autotetraploid, formed by the doubling of chromo- somes from "BB" to "BBBB" with subsequent diploidization of genomes into " $\mathrm{B}_{1} \mathrm{~B}_{1} \mathrm{~B}_{2} \mathrm{~B}_{2}$." There would probably be considerable similarity in the genomes but also numerous cryptic differences. This would account for the formation of the other bivalents at meiosis in the spore mother cells of $A$. plenum (usually some 30 -odd bivalents in addition to the 36 formed by the A. abscissum genomes) and also for the number of unpaired univalents present. ${ }^{2}$

Although the degree of pairing is high, it is apparently not sufficient for normal meiotic division and the spores formed in this manner are abortive. Even if pairing were perfect (and occasionally figures with nearly perfect pairing are observed) in the spore mother cells of $A$. plenum and the meiotic divisions normal, the spores would still probably be abortive. Such spores would receive 72 chromosomes each but would have the complement " $\mathrm{AB}_{1}$ " or " $\mathrm{AB}_{2}$ " and would most likely be inviable due to a lack of necessary genetic material carried in the missing " $B$ " genome. It is interesting to note that the meiotic spores often look normal in shape and perispore formation but that they are empty.

Discussion--The evidence here cited supports the novel hypothesis that $A$. plenum is actually a backcross hybrid between $A$. abscissum, a $2 x$ sexual species with $n=36$, and $A$. curtissii, a "sterile" $3 x$ hybrid with 108 chromosomes, having one genome of 36 chromosomes from $2 x$ A. abscissum and one complement of 72 chromosomes from $A$. verecundum. However, no such origin in which a "sterile" fern hybrid serves as a participant in the formation of a new fern species has been reported. By what mechanism, then, might such a cross be possible?

Several years ago I did extensive routine acetocarmine squashes of fern hybrids. The pairing behavior was that expected of such plants and the spores formed following erratic meiotic

\footnotetext{
${ }^{2}$ Another means by which $A$. plenum could have been formed is through hybridization of a $4 x \mathrm{~A}$. abscissum $\left(\mathrm{A}_{1} \mathrm{~A}_{1} \mathrm{~A}_{2} \mathrm{~A}_{2}\right)$ with $4 x A$. verecundum $\left(\mathrm{B}_{1} \mathrm{~B}_{1} \mathrm{~B}_{2} \mathrm{~B}_{2}\right)$. This cross would give $A$. plenum with the genetic complement " $A_{1} A_{2} B_{1} B_{2}$," which might cxhibit pairing behavior similar to that actually observed. However, the existence of a $4 x A$. abscissum has not been reported in the literature and herbarium specimens of Florida plants examined for spore size have yielded a single, uniformly small-spored type, thus giving no indication of the existence of a $4 x$ form in that region. Therefore, it seems unlikely that the hybrid A. plenum originated in this manner.
}

Fig. 2-10.-Fig. 2-6. Chromosomes of the taxa discussed.-Fig. 2. A. plenum (UMBG, Sumter Co., Fla.), 67 bivalents, 10 univalents.-Fig. 3. A. curtissii (UMBG, Sumter Co., Fla.), 17 bivalents, 74 univalents.-Fig. 4. A. verecundum (UMBG 21622, Dade Co., Fla.), 72 bivalents.-Fig. 5. A. abscissum (UMBG, Sumtor Co., Fla.), 36 bivalents.Fig. 6. A. cristatum (UMBG 21486, Citrus Co., Fla.), 36 bivalents.-Fig. 7-10. Camera lucida drawings.-Fig. 7. Unreduced spore of $A$. plenum, $52 \mu$.-Fig. 8 . Joined unreduced spores of $A$. plenum, presumably formed by a single mitotic division of a spore mother cell.--Fig. 9. Germinating spore of $A$. plenum, $430 \times$ - - Fig. 10 . Unreduced spores of $A$. curtissii, $42 \mu$. 

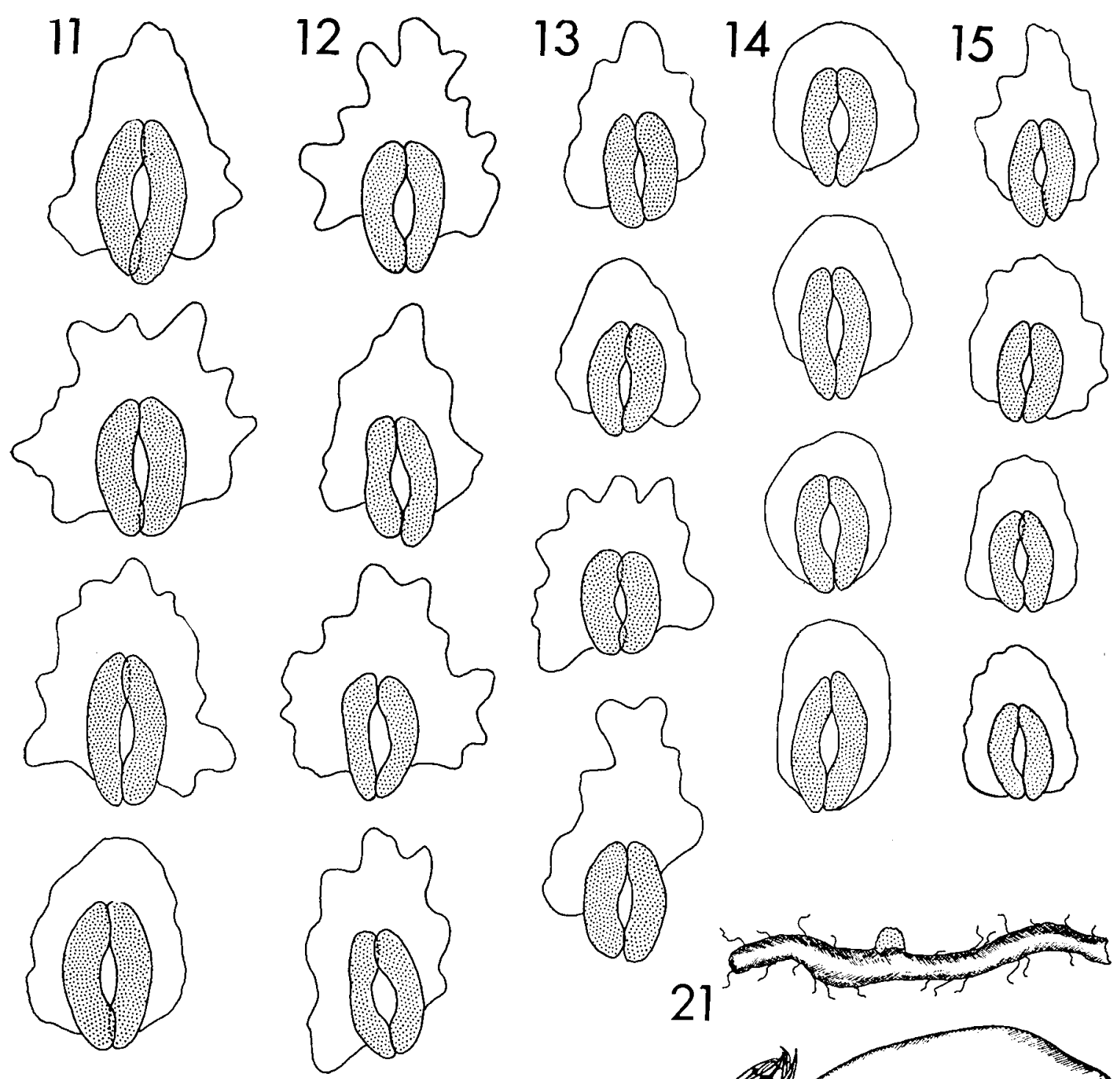

salas

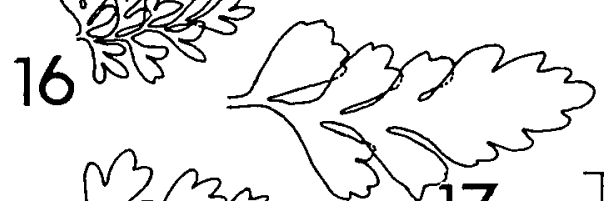

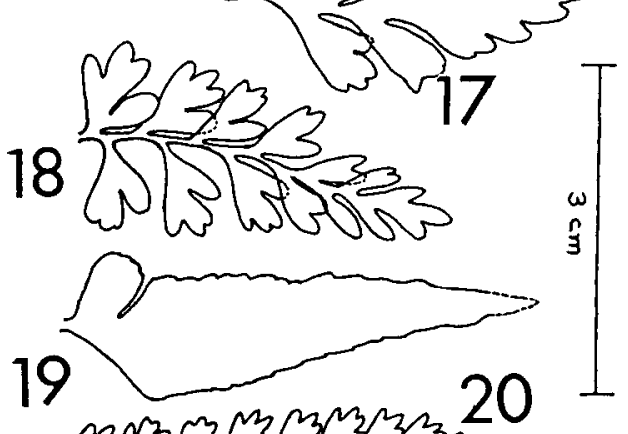

whan

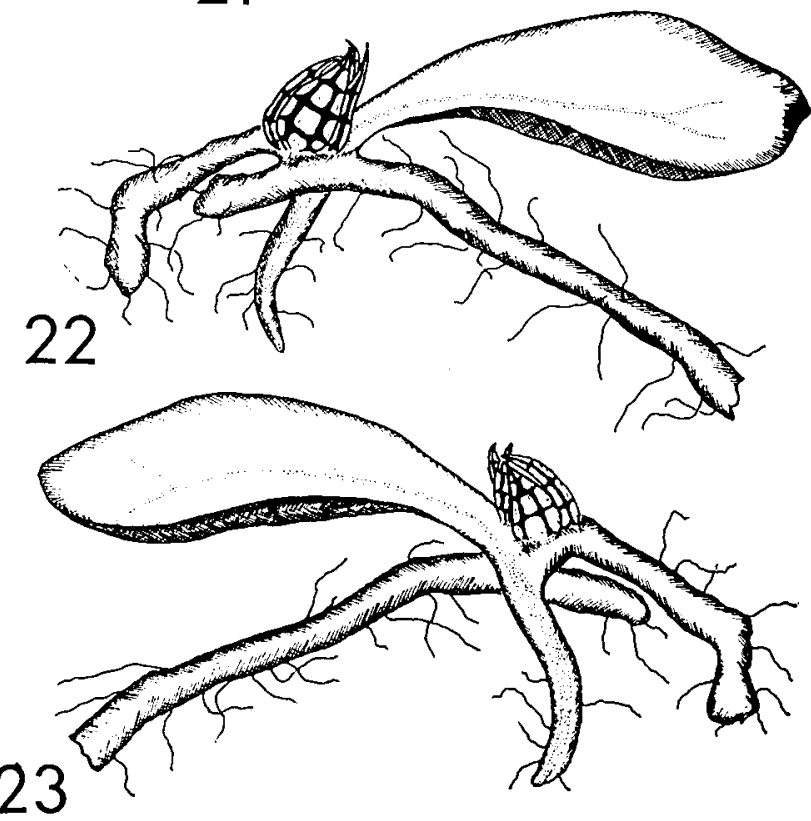



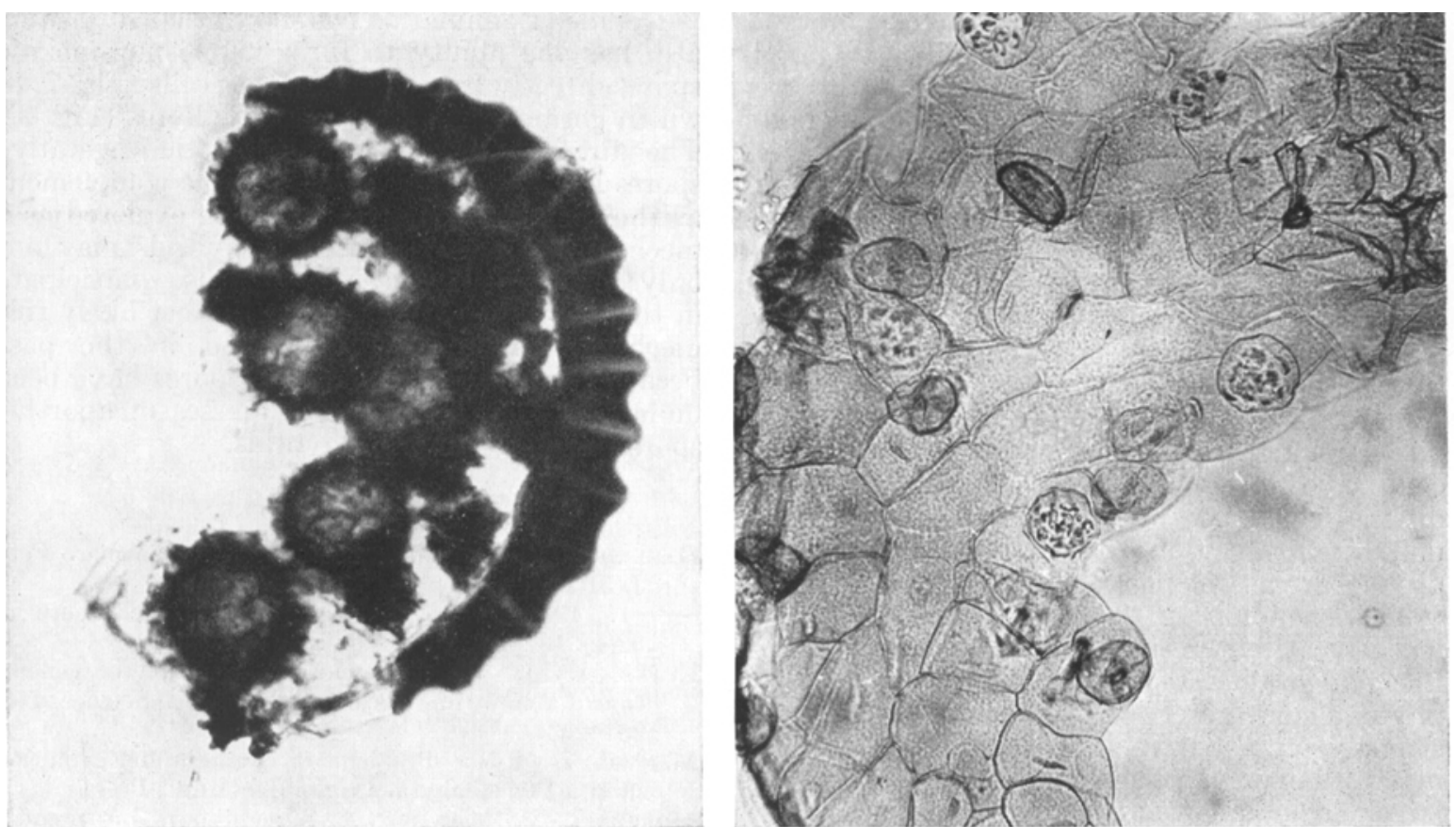

Fig. 24, 25. Sporangium and gametophyte of $A$. curtissii.-Fig. 24. Sporangium, showing five unreduced spores plus numerous abortive spores, $150 \times$.-Fig. 25. Gametophyte, showing antheridia with sperms, $100 \times$.

pairing were highly irregular, empty, and presumably inviable. However, a large, round, seemingly viable spore was occasionally observed. Usually one to several of these "spores" occurred in a single sporangium among the abortive spores (Fig. 24), but up to 16 of the large spores formed within a sporangium, the same number as the spore mother cells present in the sporangium before sporogenesis. No abortive spores occurred in the 16-spored sporangia, as shown especially well in the $3 x$ hybrid, Asplenium $\times$ trudellii $(A$. montanum $\times$ pinnatifidum). Since the spores produced by meiotic division were abortive, and since up to 16 of the round, viableappearing spores occurred in one sporangium, it was concluded that these large spores were unreduced spore mother cells which directly became spores, these having the same chromosome complement as the sporophytic plants from which they were formed. It was further hypothesized that such "giant spores" could produce gametophytes and that any sporophytes they might produce would need to develop apogamously. This, then, could provide a mechanism by which "sterile" hybrids could completely bypass the sexual cycle, meiosis being circumvented by direct conversion of spore mother cells to spores, and syngamy avoided through production of apogamous sporophytes. Meiosis, on the other hand, would lead only to the formation of non-viable, abortive spores; hence, the reproduction of these hybrids would have to be entirely by vegetative means. The large unreduced spores would thus essentially be a means of vegetative reproduction taking advantage of a part of the plant normally included in the sexual cycle, namely, the spore.

To test the hypothesis given above, these large spores from a variety of fern hybrids were sown on an inorganic agar medium; they germinated as predicted and developed into gametophytes with antheridia and archegonia (Morzenti, 1962). Since then the author has returned to more detailed research, now in progress, on this phenomenon. Some 50 different hybrids, belonging to 6 genera-Asplenium, Dryopteris, Gymnocarpium, Polypodium, Polystichum, and Pteris have been studied, and the presence of these large unreduced spores has been discovered in

Fig. 11-23.-Fig. 11-15. Camera lucida drawings of stomates, $645 \times$, showing hybrid intermediacy.-Fig. 11. A. plenum.-Fig. 12. A. curtissii.-Fig. 13. A. verecundum.-Fig. 14. A. abscissum.--Fig. 15. A. cristatum.--Fig. 16-20. Microprojector drawings of pinna outlines.-Fig. 16. A. verecundum.-Fig. 17. A. plenum.-Fig. 18. A. curtissii.-Fig 19. A. abscissum.-Fig. 20. A. cristatum.-Fig. 21-23. Camera lucida drawings of root proliferations in $A$. plenum, $15 \times$.-Fig. 21. Early proliferation just breaking through root cortex and epidermis.-Fig. 22. Young proliferation showing first leaf and root; apex covered with clathrate scales; ventral view.-Fig. 23. Same proliferation as in Fig. 22 showing dorsal view. 
almost all of them. ${ }^{3}$ Most of these sporocytic spores have demonstrated their ability to germinate and produce gametophytes with both types of sexual organs. Although large numbers of gametophytes have been obtained from these spores, a relatively small number of apogamous sporophytes have thus far been obtained. However, it seems likely that these gametophytes with an unreduced chromosome number all have the capacity to produce sporophytes apogamously. The fact is that gametophytes of normal fern species also have this ability if they are kept from fertilization (Manton, 1950). While the conditions under which the spores are sown are conducive to gametophytic growth, the conditions which best favor natural apogamy-the uninduced transition from gametophyte to sporophyte - are as yet poorly understood.

The phenomenon of direct proliferation is a mechanism by which hybrid gametophytes have the potentiality of reproducing hybrid sporophytes in nature. Field studies of some hybrids strongly suggest that this means of reproduction may well operate where the hybrid occurs over a larger area than would be expected by ordinary rhizome proliferation, and in which one or both of the parents is lacking.

As a result of these studies on spore reproduction in fern hybrids, it was hypothesized that the phenomenon of unreduced spores must be the mechanism by which the "sterile" hybrid A. curtissii could participate in the formation of A. plenum. Herbarium specimens as well as living fertile fronds of the suspected triploid parent were examined for spores. As predicted, there was much abortion but also many of the distinctive, large round spores (Fig. 10, 24). Those from fresh collections were sown on mineral agar, germinated, and produced gametophytes having antheridia with viable sperms (Fig. 25). Thus the possibility of $A$. curtissii being able to backcross with one of its parents, A. abscissum, exists. ${ }^{4}$

\footnotetext{
3 The observations I have made differ from those by Evans (1964) on Polypodium dispersum. He reported that the sporangia regularly formed 32 diplospores following a single mitotic division of the 16 spore mother cells, rather than varying numbers of spore mother cell spores. The diplospores produced peculiar prothalli which entirely lacked sex organs and proliferated sporophytes apogamously.

14 The potentiality for the formation of new species by means of viable sperm cells produced from unreduced gametophytes in the normal obligate apogamous life cycle has already been demonstrated, e.g., Walker, 1958; Morzenti and Wagner, 1962; Morzenti, 1966.
}

Detailed examination has shown that $A$. plenum also has the ability to form viable non-meiotic spores directly from spore mother cells (Fig. 7, 8) which germinate to form gametophytes (Fig. 9). The direct formation of non-meiotic vegetative spores having the same chromosome complement as the sporophytic plant should be explored as a mechanism by which "sterile" hybrids may not only reproduce themselves but also participate in the formation of new species..$^{5}$ Most likely this mechanism has been overlooked in the past because these viable sporocytic spores have been undetected among the great masses of abortive spores produced by such hybrids.

\section{LITERATURE CITED}

Darling, 'T., Jr. 1961. Florida rarities. Amer. Fern J. $51(1): 1-15$.

. 1962. More Florida rarities. Amer. Fern J. $52(4): 137-148$.

Evans, A. M. 1964. Ameiotic alternation of generations: a new life cycle in the ferns. Science 143: $261-263$

Manton, I. 1950. Problems of cytology and evolution in the Pteridophyta. Cambridge Univ. Press.

Morzenti, V. M. 1962. A first report on pseudomeiotic sporogenesis, a type of spore reproduction by which "sterile" ferns produce gametophytes. Amer. Fern J. 52: 69-79.

- 1966. Morphological and cytological data on southeastern American "blackstem spleenworts" of the Asplenium heterochroum-resiliens complex. Amer. Fern J. 56: 167-177.

$\longrightarrow$, AND W. H. WAgner, JR. 1962. Southeastern American "blackstem spleenworts" of the Asplenium heterochroum-resiliens complex. ASB Bull. 9: 40-41.

SmalL, J. K. 1938. Ferns of the southeastern states. Science Press Printing Co., Lancaster, $\mathrm{Pa}$.

Underwood, L. M. 1906 . American ferns, VI. Species added to the flora of the United States from 1900 to 1905. Bull. Torrey Bot. Club 33: 189-205.

WAGNer, W. H., JR. 1963a. A biosystematic survey of United States ferns-preliminary abstract. Amer. Fern J. 53: 1-16.

- $1963 \mathrm{~b}$. Biosystematics and taxonomic categories in lower vascular plants. Regnum Veg. 27: $63-71$.

WAlker, T. G. 1958. Hybridization in some species of Pteris L. Evolution 12: 82-92.

Wherry, E. T. 1964. The southern fern guide. Doubleday, Garden City, N. Y.

${ }^{5}$ In certain hybrids where more efficient means of vegetative reproduction are present, the unreduced spore may have less significance in reproducing the population. For example, colonies of $A$. plenum have been found with plants numbering in the hundreds (Wagner, 1963a, b). This species, having an upright rhizome, produces new sporophytic plants abundantly by proliferations from the roots (Fig. 21-23). 